Arthurita Venter (1) - Stefan Siebert • Nishanta Rajakaruna

Sandra Barnard · Anatoliy Levanets · Arshad Ismail

Mushal Allam - Bianca Peterson - Tomasz Sanko

\title{
Biological crusts of serpentine and non-serpentine soils from the Barberton Greenstone Belt of South Africa
}

\begin{abstract}
Climate and geography can influence biological soil crust (BSC) community composition, but local heterogeneity in variables such as soil characteristics or microclimate gradients can also impact cryptogamic diversity. Heavy metals and nutrient imbalances in serpentine soils are known to influence the distributions of higher plants, but cryptogamic species appear to be more tolerant of substrate. The aim of this study was to compare the cryptogamic composition of serpentine and non-serpentine soils by using integrative taxonomy, which combines morphological and DNA barcoding data, to determine how soil characteristics in combination with rainfall can influence BSC community composition. Samples from serpentine and non-serpentine soils were enumerated and total genomic DNA was isolated from the soil samples. Analyses of the 16S rRNA gene and ITS sequences were done using the quantitative insights into microbial ecology (QIIME) workflow to determine which eukaryotic microorganisms were present in the samples. Sixty genera from the Cyanophyceae (38), Chlorophyceae (10), Bacillariophyceae (6), Eustigmatophyceae (4), Trebouxiophyceae (1) and Xanthophyceae (1) classes were detected with this approach. Results confirm that algae and cyanobacteria are tolerant of most substrates and can even colonize environments with high levels of heavy metal and nutrient imbalances, if moisture is present. Genera such as Acaryochloris, Annamia, Brasilonema,
\end{abstract}

A. Venter $(\bowtie) \cdot S$. Siebert $\cdot$ N. Rajakaruna $\cdot S$. Barnard $\cdot$ A. Levanets $\cdot$ B. Peterson $\cdot$ T. Sanko

Unit for Environmental Sciences and Management, North-West University, Potchefstroom, South Africa

E-mail: 10066551@nwu.ac.za

N. Rajakaruna

Biological Sciences Department, California Polytechnic State University, San Luis Obispo, CA, USA

A. Ismail · M. Allam

Sequencing Core Facility, National Institute for Communicable Diseases, A Division of the National Health Laboratory Service, Johannesburg, South Africa
Chrocosphaera, Halomicronema, Planktothricoides, Rubidibacter, and Toxopsis are reported for the first time for South African soil.

Keywords Algae Cyanobacteria $\cdot$ Metagenomics · Microbial diversity $\cdot$ Serpentine geoecology

\section{Introduction}

Climate and geography can influence biological soil crust (BSC) community composition, but local heterogeneity in variables such as soil characteristics or microclimate gradients can also impact cryptogamic diversity (Belnap 2006). BSCs can be tolerant of harsh environments such as extreme temperatures, drought (Belnap 2006) and heavy metals (Orlekowsky et al. 2013). BSCs are also found on serpentine soils (Venter et al. 2015), that are usually rich in magnesium and poor in calcium, with low nutrient and high heavy metal concentrations (Alexander et al. 2007; Rajakaruna et al. 2009). Cyanobacteria and algae make up a large component of BSCs and Venter et al. (2015) found typical cyanobacteria and soil algae such as Leptolyngbya, Microcoleus, Phormidium, Chlamydomonas, Chlorococcum and Hantzchia in serpentine as well as non-serpentine soils but algae such as Chroococcus sp., Scytonema ocellatum, Nostoc linckia, Chlorotetraedron sp., Hormotilopsis gelatinosa, Klebsormidium flaccidum, Pleurococcus sp. and Tetracystis elliptica were only found on serpentine soils. A study by Pessoa-Filho et al. (2015) showed differences in bacterial community structures between non-serpentine and serpentine sites, but concluded that the presence of different plant communities may have influenced the structure and functioning of the bacterial communities. It seems that algae and cyanobacteria are able to survive the nutrient deficient nature and distinct chemistry of ultramafic habitats if moisture is available (Cabala et al. 2011; Orlekowsky et al. 2013). Budel et al. (2009) investigated BSC diversity in southern Africa from the Namibian-Angola 
border in the north, down to the Cape Peninsula in the south, and concluded that the frequency of precipitation plays an important role in the diversity of BSCs. The aim of this study was to compare the composition of BSCs on serpentine and non-serpentine soils to determine how soil characteristics and rainfall can influence BSC community composition by using integrative taxonomy, which combines morphological and DNA barcoding data. Barcoding does not replace traditional taxonomy, but complements morphological taxon delineation (Pires and Marinoni 2010) to provide a more detailed and comprehensive understanding of species diversity (Smith et al. 2008). This paper will focus on the cyanobacterial and algal component of the BSCs.

\section{Methods}

\section{Sampling sites}

Serpentine outcrops in the Barberton Greenstone Belt occur in mountainous areas and are heterogeneous in altitude, slope, soil depth and other topographic features (Williamson and Balkwill 2015). Soil was sampled in February 2016 at different sampling localities along the Barberton Greenstone Belt in Mpumalanga, South
Africa (Fig. 1 and Table 1). Samples 1, 3, 5, 7, 9 11, 13 and 15 were collected from serpentinite outcrops and samples $2,4,6,8,10,12,14$, and 16 on sites with nonserpentinite geology. Mean annual temperatures of the study area vary between 16.7 and $20.9{ }^{\circ} \mathrm{C}$ and mean annual summer rainfall ranges from 518 to $1194 \mathrm{~mm}$ (Mucina and Rutherford 2006). The Drakensberg Escarpment divides Mpumalanga province into a westerly half consisting mainly of high-altitude grassland called the Highveld and an eastern half situated in low altitude subtropical Lowveld, mostly savanna habitat (Williamson and Balkwill 2015). Sites 1, 2, and 11-16 were sampled along the escarpment and are situated in a cool (mean annual temperature of $17^{\circ} \mathrm{C}$ ) mist belt with a high frequency of fog and precipitation levels ( $>1000 \mathrm{~mm}$ per annum), compared to sites 3-10 which are in subtropical Lowveld $\left(19.7{ }^{\circ} \mathrm{C} ;<800 \mathrm{~mm}\right)$. At each site, visible BSC and soil were sampled for identification and enumeration, as well as metagenomic classification.

\section{Identification and enumeration}

Samples were enriched with GBG11 growth medium (Kruger 1978) and incubated at $20^{\circ} \mathrm{C}$ and a light

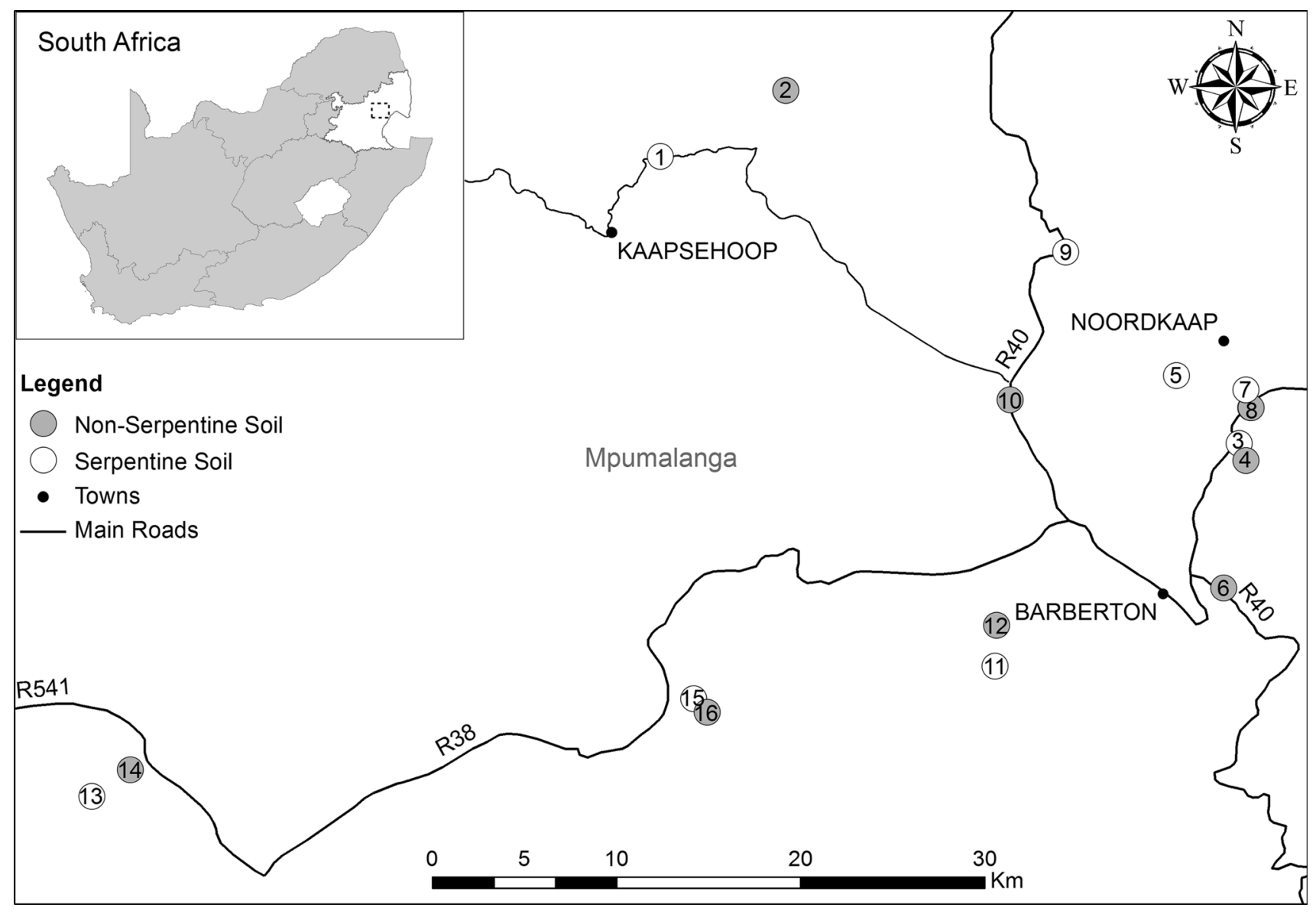

Fig. 1 Sample sites in Mpumalanga. White circles are the serpentine sites and the darker circles the non-serpentine sites 
Table 1 Information about the sample sites

\begin{tabular}{|c|c|c|c|c|c|c|}
\hline Site & Geology & $\begin{array}{l}\text { Latitude } \\
\text { (DDD }{ }^{\circ} \text { MM.l }\end{array}$ & $\begin{array}{l}\text { Longitude } \\
\left.I^{\prime}\right)\end{array}$ & Altitude (m) & Description & Vegetation \\
\hline 1 & Serpentinite & S $25^{\circ} 33.604^{\prime}$ & E $30^{\circ} 47.456^{\prime}$ & 1304.92 & & \\
\hline 2 & Granite red soil & S $25^{\circ} 31.667^{\prime}$ & E $30^{\circ} 51.129^{\prime}$ & 965.85 & Kaapsehoop & Grassland \\
\hline 3 & Serpentinite & S $25^{\circ} 42.014^{\prime}$ & E $31^{\circ} 04.436^{\prime}$ & 607.08 & Noordkaap railway & Bushveld \\
\hline 4 & Basalt & S $25^{\circ} 40.333^{\prime}$ & E $31^{\circ} 07.629^{\prime}$ & 608.00 & Noordkaap railway & Bushveld \\
\hline 5 & Serpentinite & S $25^{\circ} 40.021^{\prime}$ & E $31^{\circ} 02.584^{\prime}$ & 688.00 & Mundt's concession & Ecotone \\
\hline 6 & Diorite & S $25^{\circ} 46.257^{\prime}$ & E $31^{\circ} 03.976^{\prime}$ & 948.00 & Geological trail & Ecotone \\
\hline 7 & Serpentinite & S $25^{\circ} 40.961^{\prime}$ & E $31^{\circ} 04.770^{\prime}$ & 593.54 & Noordkaap reserve & Bushveld \\
\hline 8 & Basalt & S $25^{\circ} 41.077^{\prime}$ & E $31^{\circ} 04.741^{\prime}$ & 594.15 & Noordkaap reserve & Bushveld \\
\hline 9 & Serpentinite & S $25^{\circ} 36.400^{\prime}$ & E $30^{\circ} 59.340^{\prime}$ & 746.15 & R40 Pass & Ecotone \\
\hline 10 & Granite & S $25^{\circ} 40.721^{\prime}$ & E $30^{\circ} 57.709^{\prime}$ & 803.69 & R40 Pass & Ecotone \\
\hline 11 & Serpentinite & S $25^{\circ} 48.544^{\prime}$ & E $30^{\circ} 57.260^{\prime}$ & 883.38 & Sassenheim & Ecotone \\
\hline 12 & Quartzite & S $25^{\circ} 47.345^{\prime}$ & E $30^{\circ} 57.313^{\prime}$ & 830.46 & Sassenheim & Ecotone \\
\hline 13 & Serpentinite & S $25^{\circ} 52.355^{\prime}$ & E $30^{\circ} 30.791^{\prime}$ & 1255.00 & Kalkkloof & Grassland \\
\hline 14 & Quartzite & S $25^{\circ} 51.575^{\prime}$ & E $30^{\circ} 31.919^{\prime}$ & 1240.00 & Kalkkloof & Grassland \\
\hline 15 & Serpentinite & S $25^{\circ} 49.501^{\prime}$ & E $30^{\circ} 48.432^{\prime}$ & 1409.00 & Nelshoogte & Grassland \\
\hline 16 & Diorite & S $25^{\circ} 49.901^{\prime}$ & E $30^{\circ} 48.827^{\prime}$ & 1364.00 & Nelshoogte & Grassland \\
\hline
\end{tabular}

intensity of $35 \mu \mathrm{mol} \mathrm{m}{ }^{-2} \mathrm{~s}^{-1}$ to enhance the identification of the algal and cyanobacteria genera present. Genera were identified microscopically using a Nikon $80 \mathrm{i}$ microscope with differential interference contrast, " $\mathrm{n}$ 60X Plan Apochromatic 1.4 Numerical aperture (NA), oil violet corrected with a 1.4 NA oil condenser. Literature used for identification was Ettl et al. (1999), Hindak (2008), Huber-Pestalozzi (1961), John et al. (2002), Komarek and Anagnostidis (2005), Taylor et al. (2007) and Wehr and Sheath (2003).

Ten grams of the crust was diluted up to $100 \mathrm{ml}$ with distilled water in $250 \mathrm{ml}$ screw top bottles and preserved with $2 \%$ formaldehyde. The suspension was shaken for $1 \mathrm{~min}$ and left for $10 \mathrm{~min}$ to settle. One milliliter of the suspension was diluted with $1 \mathrm{ml}$ distilled water and algal and cyanobacterial cells were then counted with a Sedgwick rafter chamber. This was repeated for each sample. The counting was done according to the method described in Hotzel and Croome (1999).

\section{Chlorophyll-a analysis}

A method adapted from Castle (2010) and described in Orlekowsky et al. (2013) was used to measure chlorophyll- $a$ analysis. The crust was lifted to separate it from the soil below. Three grams of crust was added to $9 \mathrm{ml}$ methanol solution in a $15 \mathrm{ml}$ screw top bottle; shaken for $4 \mathrm{~h}$ and then filtered through a Whatman GF/C filter. The supernatant was analysed with a spectrophotometer at 652, 665 and $750 \mathrm{~nm}$. The following equation (described in Henriques et al. 2007) was used to determine the chlorophyll- $a$ (in micrograms) in the soil: $\mu \mathrm{g}$ Chl- $a \mathrm{~g}^{-1} \quad$ soil $=((16.29 \times[\mathrm{A} 665-\mathrm{A} 750])-(8.54 \times[$ $\mathrm{A} 652-\mathrm{A} 750]) \times \mathrm{v}) /(1 \times \mathrm{V})$, where $\mathrm{v}=$ volume of solvent used $(\mathrm{ml}) ; 1=$ the spectrophotometric cell length $(\mathrm{cm})$ and $\mathrm{V}=$ the sample volume $(\mathrm{g})$.

\section{DNA extraction}

DNA extractions from the soil samples were done using the Power ${ }^{\circledR}$ Soil DNA extraction kit (MO-BIO Laboratories, Carlsbad, CA). The manufacturer's instructions were followed with the additional step of a Proteinase $\mathrm{K}$ treatment. DNA was eluted in $100 \mu \mathrm{l}$ of the eluent provided by the PowerMax Soil DNA kit. DNA extracted from the soil samples was quantified using a NanoDrop Spectrophotometer (ND 1000, BioRad).

16S rRNA/ITS gene amplification and MiSeq sequencing

The V3-V4 variable region of the 16S rRNA gene and nuclear ribosomal internal transcribed spacer (ITS) regions including the $5.8 \mathrm{~S}$ gene were amplified from 16 soil DNA extracts using the 16S and ITS metagenomic sequencing library protocol (Illumina). For $16 \mathrm{~S}$ and ITS library preparations, two PCR reactions were completed on the template DNA. Initially the DNA was amplified with primers specific to the V3-V4 region of the $16 \mathrm{~S}$ rRNA gene (Klindworth et al. 2013) and the ITS1-ITS4 primer pair was used to amplify the intervening $5.8 \mathrm{~S}$ rDNA and the adjacent ITS1 and ITS2 regions (White et al. 1990). Both 16S and ITS primer pairs incorporated the Illumina overhang adaptor (16S Forward primer 5'TCGTCGGCAGCGTCAGATGTGTATAAGAGACAGCCTACGGGNGGCWGCAG; 16S reverse primer 5'GTCTCGTGGGCTCGGAGATGTGTATAAGAGACAGGACTACHVGGGTATCTAATCC; ITS1 primer 5'TCGTCGGCAGCGTCAGATGTGTATAAGAGACAGTCCGTAGGTGAACCTGCGG; and ITS 4 primer $5^{\prime}$ GTCTCGTGGGCTCGGAGATGTGTA TAAGAGACAGTCCTCCGCTTATTGATATGC). 
Each PCR reaction contained DNA template $(\sim 12 \mathrm{ng}), 5 \mu \mathrm{l}$ forward primer $(1 \mu \mathrm{M}), 5 \mu \mathrm{l}$ reverse primer $(1 \mu \mathrm{M}), 12.5 \mu \mathrm{l} 2 \mathrm{X}$ Kapa HiFi Hotstart ready mix (KAPA Biosystems Woburn, MA), and PCR grade water to a final volume of $25 \mu \mathrm{l}$. PCR amplification was carried out as follows: heated lid $110{ }^{\circ} \mathrm{C}, 95^{\circ} \mathrm{C} \times 3 \mathrm{~min}$, 25 cycles of $95{ }^{\circ} \mathrm{C} \times 30 \mathrm{~s}, 55^{\circ} \mathrm{C} \times 30 \mathrm{~s}, 72{ }^{\circ} \mathrm{C} \times 30 \mathrm{~s}$, then $72{ }^{\circ} \mathrm{C} \times 5 \mathrm{~min}$ and held at $4{ }^{\circ} \mathrm{C}$. Negative control reactions without any template DNA were carried out simultaneously.

PCR products were visualised using gel electrophoresis (1X TAE buffer, $1.5 \%$ agarose, $100 \mathrm{~V}$ ). Successful PCR products were cleaned using AMPure XP magnetic bead based purification (Beckman Coulter, IN). The Illumina Nextera XT Index kit (Illumina, San Diego, CA) with dual 8-base indices were used to allow for multiplexing. Two indexing primers were used per sample. Each PCR reaction contained purified DNA $(5 \mu \mathrm{l}), 5 \mu \mathrm{l}$ index 1 primer, $5 \mu \mathrm{l}$ index 2 primer, $25 \mu \mathrm{l} 2 \mathrm{X}$ Kapa HiFi Hot Start Ready mix and $10 \mu \mathrm{PCR}$ grade water. PCR reactions were performed on a Bio-Rad C1000 Thermal Cycler (Bio-Rad, Hercules, CA) Cycling conditions consisted of one cycle of $95{ }^{\circ} \mathrm{C}$ for $3 \mathrm{~min}$, followed by eight cycles of $95^{\circ} \mathrm{C}$ for $30 \mathrm{~s}, 55^{\circ} \mathrm{C}$ for $30 \mathrm{~s}$ and $72{ }^{\circ} \mathrm{C}$ for $30 \mathrm{~s}$, followed by a final extension cycle of $72{ }^{\circ} \mathrm{C}$ for $5 \mathrm{~min}$.

Prior to library pooling, the indexed libraries were purified with Ampure XP beads and quantified using the Qubit dsDNA HS Assay Kit (Thermo Fisher Scientific, Waltham, MA). Purified amplicons were run on the Agilent Bioanalyzer (Agilent Technologies, Santa Clara, CA) for quality analysis prior to sequencing. The sample pool $(2 \mathrm{nM})$ was denatured with $0.2 \mathrm{~N} \mathrm{NaOH}$, then diluted to $7 \mathrm{pM}$ and combined with $10 \%(\mathrm{v} / \mathrm{v})$ denatured $20 \mathrm{pM}$ PhiX, prepared following Illumina guidelines. Samples were sequenced on the MiSeq sequencing platform at the NICD sequencing core facility, using a $2 \times 300$ cycle V3 kit, following standard Illumina sequencing protocols. The raw sequence reads are available at the National Center for Biotechnology Information Short Read Archive (NCBI SRA) (Accession numbers SRR 617 6964-SRR 617 6995).

\section{Data processing}

The FastQC (v0.0.13) tool (Andrews 2010) was used to determine the quality of the raw reads, after which Trimmomatic (v0.36) (Bolger et al. 2014) was used to remove adapters and short (less than 25 nucleotides) and low quality (quality score lower than 15) reads. Subsequently, part of the workflow of Shade (2015) was used for amplicon analysis using QIIME (quantitative insights into microbial ecology) (Caporaso et al. 2010b). Trimmed forward and reverse reads were merged according to a simple bayesian algorithm using the paired-end Assembler for DNA sequences (PANDAseq) module (Masella et al. 2012). All merged sequences were then combined into a single
FASTA file with QIIME labels, followed by de novo operational taxonomic unit (OTU)-picking using the usearch61 application (Edgar 2010). The latter step clustered sequences into OTUs at $97 \%$ sequence identity to filter noisy reads and correct errors. OTUs were subsequently identified by using Basic Local Alignment Search Tool (BLAST) (Altschul et al. 1990) against a locally created database consisting of $\sim 215 \mathrm{k}$ cyanobacterial and algal sequences. Prior to taxonomy assignment, sequences were aligned to the Greengenes Core reference alignment (DeSantis et al. 2006) using PyNAST (Caporaso et al. 2010a). Bacterial, and hence cyanobacterial, taxonomies were assigned to OTUs by matching the accession numbers from BLAST results against the Greengenes taxonomy and reference database (McDonald et al. 2012) using the RDP classifier (v2.2) (Wang et al. 2007). Additionally, accession numbers from BLAST results were also matched against a locally created NCBI algal taxonomy database to assign these taxonomies. The latter database was compiled using the workflow of Baker (2016). Taxonomy assignment was then followed by visualisation in R (v.3.3.3) using the ggplot2 package (Wickham 2009).

\section{Soil analyses}

Analyses were done in accordance with the standards set out by the Agricultural Laboratory Association of Southern Africa (ALASA) and the International Soil Analytical Exchange (ISE), Wageningen, The Netherlands, control schemes. Exchangeable $\mathrm{Ca}, \mathrm{Mg}, \mathrm{K}$ and $\mathrm{Na}$ were estimated by $1 \mathrm{M}$ ammonium acetate $(\mathrm{pH} 7)$ extraction, $\mathrm{P}$ was estimated by $\mathrm{P}-\mathrm{Bray} 1$ extraction, $\mathrm{pH}$ was estimated via 1:2.5 extraction and EC (conductivity) was determined with a saturated extraction. These methods followed NSSSA (1990). All heavy metals, including $\mathrm{Co}, \mathrm{Cr}, \mathrm{Fe}, \mathrm{Mn}$ and $\mathrm{Ni}$ as well as \% $\mathrm{N}$ and $\mathrm{S}$ were estimated by EPA method 3050b (US EPA 1996).

\section{Data analyses}

CANOCO (v 4.5) software was used to perform Principal Component Analysis (PCA) on the nutrient and chemical variables of the different sites (Ter Braak and Smilauer 1998). The differences between the datasets were determined with Statistica (v 13.2) software. The Kolmogorov-Smirnov and Lilliefors test for normality was used to determine whether the datasets were distributed parametrically. The data did not meet the assumptions of normality in the distribution of all variables and therefore the KruskalWallis ANOVA was used (non-parametric data) for comparing multiple independent samples to determine differences between the sampling sites. Spearman's rank correlation coefficient was used to find any significant correlations. 


\section{Results}

Approximately 1.5 million reads were obtained with sequencing of $16 \mathrm{~S}$ and ITS fragments isolated from the sixteen samples. Sequenced reads had lengths of between 35 and $301 \mathrm{bp}$, with an average GC content of 54.6\%. The mean sequence quality (Phred score) was 33.46, indicating $99.95 \%$ base call accuracy. After trimming, a total of $97.9 \%$ clean read pairs remained for downstream analyses. Following PANDAseq and de novo OTU picking, a total of 532412 combined merged sequences resulted in 151354 clusters, i.e. OTUs, with a specified sequence identity threshold of $97 \%$. According to BLAST results, $126050(83.3 \%)$ of OTUs could be identified from the local cyanobacterial and algal sequence database.

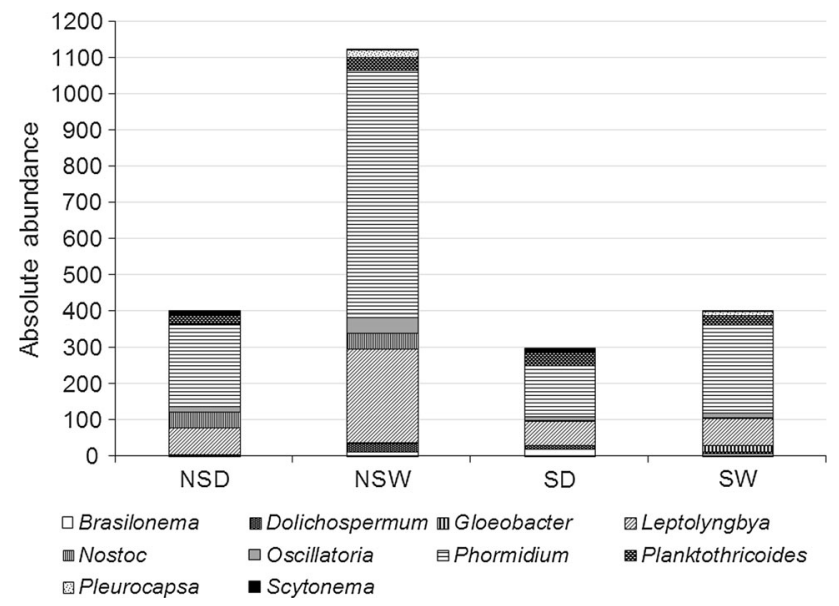

Fig. 2 Stacked bar plots illustrating the absolute abundance of the classified cyanobacteria genera (excluding low abundance genera) present in each sample group. Sample groups: $N S D$ non-serpentine soil from dry region, $N S W$ non-serpentine soil from wet region, $S D$ serpentine soil from dry region, $S W$ serpentine soil from wet region

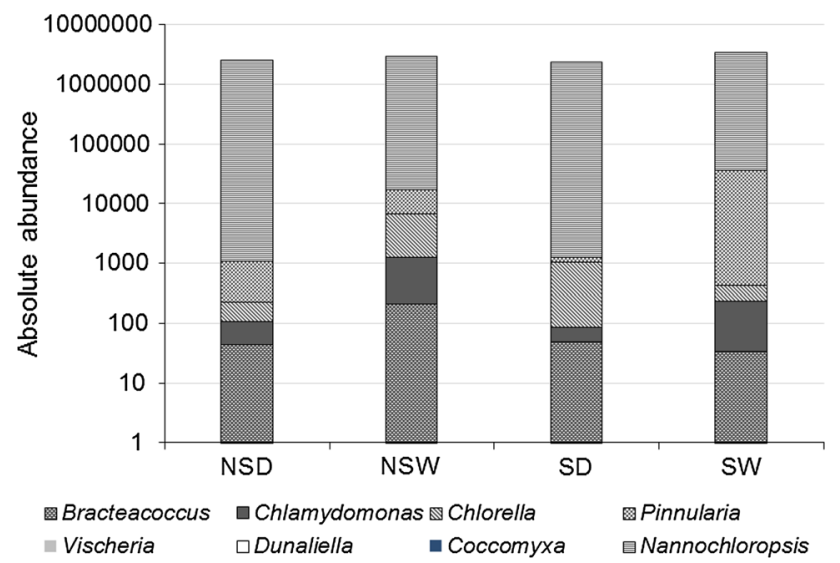

Fig. 3 Stacked bar plots illustrating the absolute abundance of the classified eukaryotic genera (excluding low abundance genera) present in each sample group. Sample groups: $N S D$ non-serpentine soil from dry region, $N S W$ non-serpentine soil from wet region, $S D$ serpentine soil from dry region, $S W$ serpentine soil from wet region
Sequencing revealed the presence of cyanobacteria and four algal classes (Bacillariophyceae, Chlorophyceae, Eustigmatophyceae and Trebouxiophyceae) in all sample groups (NSD, NSW, SD, SW). Cyanobacteria and algae were more abundant in the wetter regions (Figs. 2, 3). Thirty-four genera representing the cyanobacteria occurred in all the samples that were sequenced but only 9 occurred in all the sample groups. From highest to lowest abundance, these included Phormidium, Leptolyngbya, Planktothricoides, Nostoc, Oscillatoria, Dolichospermum, Scytonema, Arthronema and Calothrix. Pinnularia was the only genus identified within the Bacillariophyceae, while the Chlorophyceae were represented by four genera, namely Bracteacoccus, Chlamydomonas, Chlorella, and Chlorococcum, of which the latter genus was only found in non-serpentine soil at very low frequencies ( $\mathrm{n}<10$ per sample group).

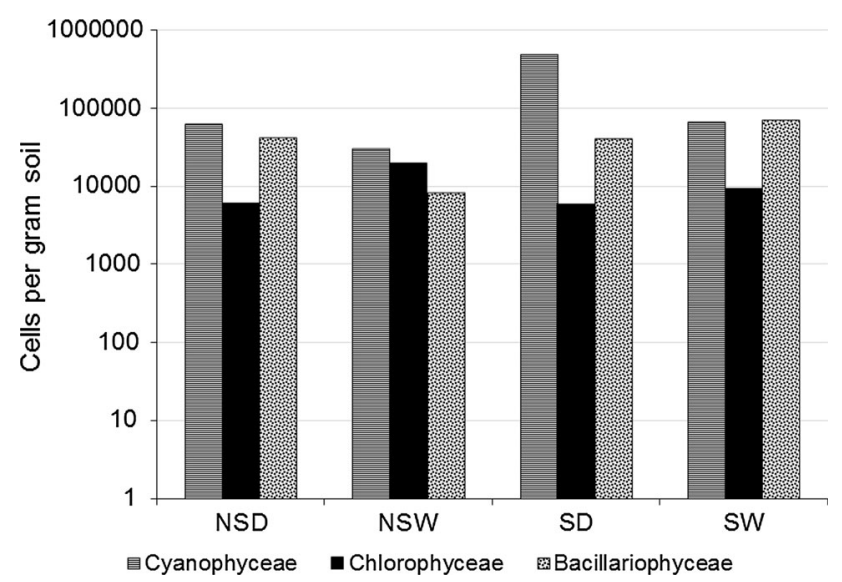

Fig. 4 Results of the enumeration of samples grouped in the following categories: $N S D$ non-serpentine soil from dry region, $N S W$ non-serpentine soil from wet region, $S D$ serpentine soil from dry region, $S W$ serpentine soil from wet region. Results are given in cells per gram soil

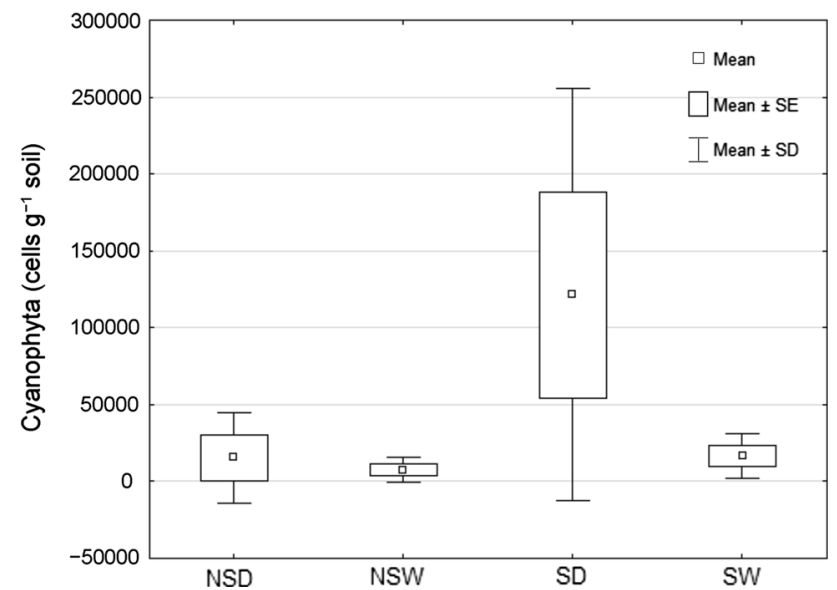

Fig. 5 Comparison of cyanobacteria (cells/g soil) in $N S D$ nonserpentine soil from dry region, $N S W$ non-serpentine soil from wet region, $S D$ serpentine soil from dry region, $S W$ serpentine soil from wet region. Results are given in cells per gram soil 


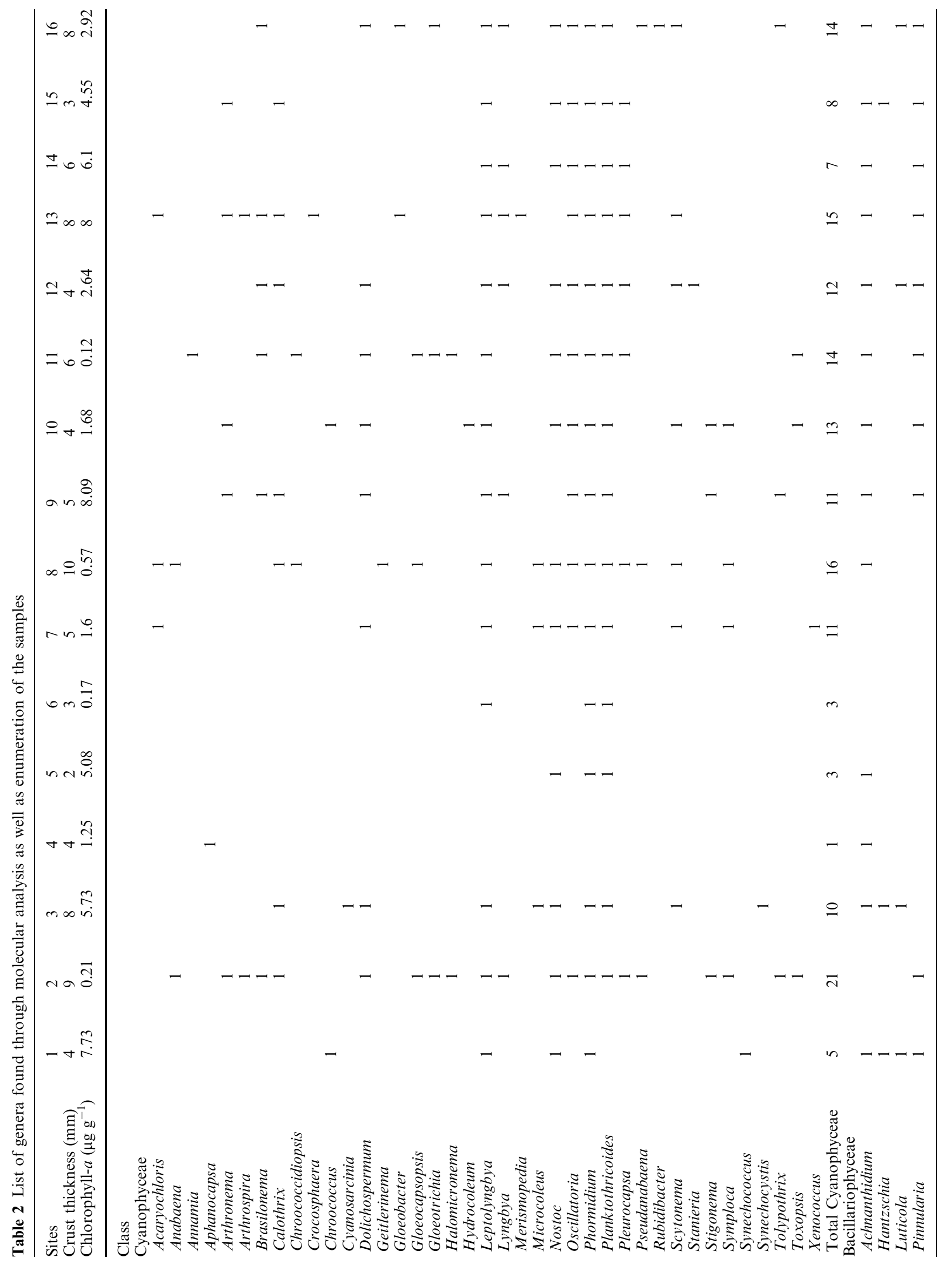




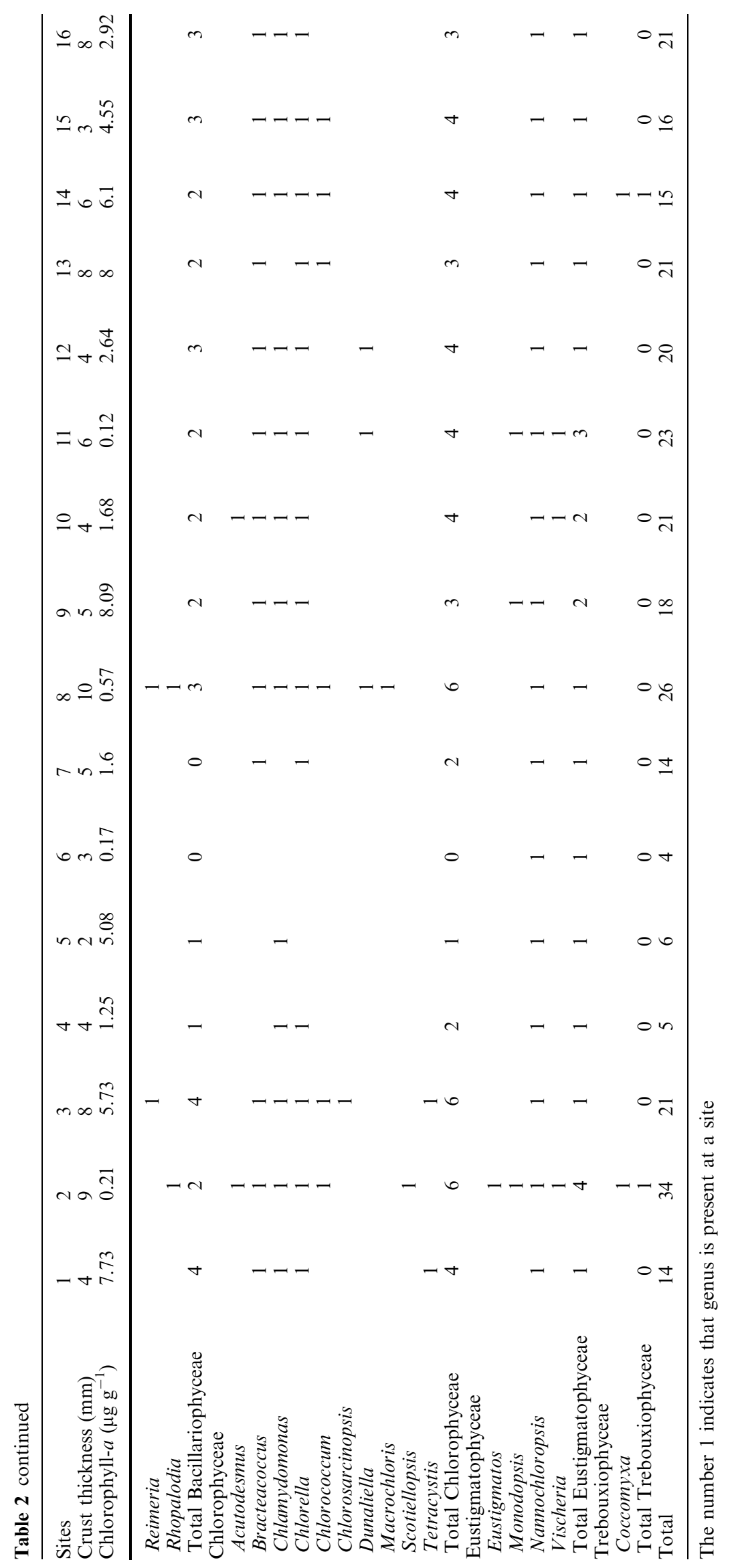


Eustigmatophyceae was represented by three genera, namely Monodopsis, Nannochloropsis, and Vischeria. Nannochloropsis, was abundant in all sample groups and was also observed in all the sites. The other genera from the Eustigmatophyceae occurred at low frequencies $(\mathrm{n}<20)$.

Absolute abundance is the number of times that sequences of these genera were detected in the sample (Figs. 2, 3). Genera that occurred less than ten times in all samples and groups were excluded due to this low abundance.

According to sequence analyses, diversity of algae and cyanobacteria was higher in the region with higher rainfall than the region with low rainfall. However, enumeration of the samples did not find any statistically significant difference $(P>0.05)$ between the sample groups as shown in Fig. 4. Cyanobacterial concentrations were slightly higher in all samples. A cyanobacterial concentration of 343000 cells $/ \mathrm{g}$ soil was observed in the drier serpentine soil sampled near the Northern Cape railway (site 3). A box plot of the number of cyanobacterial cells per gram soil comparing the wet and dry regions clearly showed that cyanobacteria were more abundant in the drier serpentine soil (Fig. 5). The highest number of Bacillariophyceae (52400 cells/g soil) was observed in the serpentine soil near Nelshoogte (site 15 ) and the most Chlorophyceae (10333 cells/g soil) was observed at Kalkkloof sampled from quartzite (site 14): both sites are situated along the wetter escarpment (Fig. 1).

Table 2 provides a complete list of all genera detected sixty in total, in the enriched media, through enumeration as well as molecular analyses for all sites. These include thirty-nine cyanobacteria genera; 10 from the Chlorophyceae; 6 from the Bacillariophyceae; 4 from the Eustigmatophyceae and one from the Trebouxiophyceae. Nostoc, Oscillatoria, Phormidium, Planktothricoides, Leptolyngbya, from the Cyanophyceae; Achnanthidium and Pinnularia from the Bacillario- phyceae; Chlamydomonas, Chlorella, Bracteacoccus from the Chlorophyceae; and Nannochloropsis from Eustigmatophyceae occurred in most of the sites. The nonserpentine site (site 2) situated in the region with higher annual rainfall had the highest diversity of algae and cyanobacteria (34). The algal biomass (chlorophyll$a$ concentration is $0.21 \mu \mathrm{g} \mathrm{g}^{-1}$ soil; Table 2) of this BSC was very low and all these genera were detected through sequencing and were not observed during the enumeration of this sample. Although the algal component was limited, the thick crust ( $9 \mathrm{~mm}$; Table 2) had a diverse fungal component (3000 different fungal spores/g soil), as well as amoeboid cells (4750 cells/g soil) and ciliates (250 cells/g soil). ITS analyses detected 26 fungal genera in this crust with the Dothideomycetes well-represented. This is the first time that cyanobacteria genera such as Brasilonema and Toxopsis from the Nostocales; Planktothricoides from the Oscillatoriales; and Halomicronema from the Synechococcales, were reported for South African soil. Other first-time genera include Chrocosphaera (site 13) and Rubidibacter (site 16) from Chroococcales as well as Acaryochloris (site 7, 8, and 13) and Annamia (site 11) from Synechococcales. Toxopsis is a close relative of Tolypothrix and was found in a cave in Greece by Lamprinou et al. (2012), who also described it. Chlorophyll- $a$ contents of most BSCs grown on serpentine soils were higher than those grown on non-serpentine soils in the same area except those grown on quartzite in Sassenheim (Table 2). Crust chlorophyll content can vary greatly due to the variety of organisms involved. Specifically, the presence of mosses and lichens can increase the chlorophyll content. According to $\mathrm{Bu}-$ del et al. (2009), a well-developed cyanobacteria crust is about $4 \mathrm{~mm}$ thick, with a high biomass and dark discoloration, with filamentous cyanobacteria such as Phormidium and Nostoc present. Spearman Rank Order did not detect a correlation between crust thickness and chlorophyll- $a(r=0.05)$ but there were significant correlations between crust thickness and cyanobacteria

Table 3 Nutrient status and particle size distribution of soil

\begin{tabular}{|c|c|c|c|c|c|c|c|c|c|}
\hline \multirow[t]{2}{*}{ Sites } & \multirow[t]{2}{*}{$\mathrm{pH}\left(\mathrm{H}_{2} \mathrm{O}\right)$} & \multirow[t]{2}{*}{$\mathrm{EG}\left(\mathrm{mS} \mathrm{m}^{-1}\right)$} & \multicolumn{3}{|c|}{ Nutrient status } & \multicolumn{3}{|c|}{ Particle size distribution } & \multirow[t]{2}{*}{ Clay } \\
\hline & & & $\% \mathrm{~N}$ & $\% \mathrm{~S}$ & $\% \mathrm{C}$ & $>2 \mathrm{~mm}(\%)$ & Sand $(\%<2 \mathrm{~mm})$ & Silt & \\
\hline 1 & 6.05 & 24 & 0.0544 & 0.0024 & 0.7254 & 10.5 & 61.6 & 30.6 & 7.8 \\
\hline 2 & 6.59 & 13 & 0.0471 & 0.0056 & 0.9603 & 1.7 & 52.2 & 16.1 & 31.7 \\
\hline 3 & 6.50 & 34 & 0.1380 & 0.0017 & 1.7266 & 22.4 & 72.2 & 22.7 & 5.0 \\
\hline 4 & 6.75 & 53 & 0.2224 & 0.0318 & 2.4300 & 15.1 & 62.9 & 28.9 & 8.1 \\
\hline 5 & 6.22 & 21 & 0.3523 & 0.0297 & 4.4400 & 17.6 & 40.2 & 38.7 & 21.1 \\
\hline 6 & 6.15 & 25 & 0.2665 & 0.0304 & 4.4400 & 25.8 & 46.6 & 35.7 & 17.7 \\
\hline 7 & 6.20 & 61 & 0.3369 & 0.0530 & 3.7903 & 31.7 & 53.8 & 36.0 & 10.1 \\
\hline 8 & 6.40 & 49 & 0.4183 & 0.0415 & 5.8200 & 12.4 & 73.2 & 16.0 & 10.8 \\
\hline 9 & 6.38 & 46 & 0.5420 & 0.0315 & 6.4900 & 11.7 & 51.5 & 32.4 & 16.1 \\
\hline 10 & 6.78 & 20 & 0.0695 & 0.0111 & 1.7470 & 14.3 & 78.7 & 9.9 & 11.5 \\
\hline 11 & 6.20 & 51 & 0.2519 & 0.0311 & 3.9129 & 25.6 & 42.0 & 43.9 & 14.0 \\
\hline 12 & 6.42 & 13 & 0.0846 & 0.0034 & 1.4099 & 16.1 & 82.9 & 7.7 & 9.4 \\
\hline 13 & 6.08 & 22 & 0.4923 & 0.0505 & 6.3800 & 26.5 & 75.8 & 18.6 & 5.6 \\
\hline 14 & 5.83 & 17 & 0.1602 & 0.0213 & 2.5950 & 0.3 & 66.5 & 17.2 & 16.3 \\
\hline 15 & 6.33 & 22 & 0.2652 & 0.0328 & 4.1400 & 22.7 & 74.6 & 17.0 & 8.4 \\
\hline 16 & 6.28 & 14 & 0.2137 & 0.0264 & 2.8810 & 13.2 & 54.5 & 29.3 & 16.2 \\
\hline
\end{tabular}


Table 4 Some of the metals present in soil samples measured in $\mathrm{mg} \mathrm{kg}^{-1}$

\begin{tabular}{lrrlrrlrr}
\hline Sites & \multicolumn{1}{c}{$\mathrm{Mg}$} & $\mathrm{Ca}$ & $\mathrm{Ca} / \mathrm{Mg}$ & $\mathrm{Cr}$ & $\mathrm{Mn}$ & $\mathrm{Fe}$ & $\mathrm{Co}$ & $\mathrm{Ni}$ \\
\hline 1 & 11000 & 828 & 0.08 & 229 & 910 & 64200 & 63 & 198 \\
2 & 1200 & 477 & 0.38 & 84 & 140 & 28200 & 10 & 34 \\
3 & 39800 & 26200 & 0.66 & 1600 & 930 & 38700 & 43 & 387 \\
4 & 25800 & 6900 & 0.27 & 710 & 1040 & 35800 & 39 & 308 \\
5 & 23900 & 2100 & 0.09 & 1450 & 1570 & 69500 & 153 & 1874 \\
6 & 7660 & 3300 & 0.42 & 670 & 760 & 41800 & 39 & 144 \\
7 & 25300 & 8400 & 0.33 & 1100 & 1000 & 48900 & 66 & 793 \\
8 & 4300 & 5400 & 1.26 & 200 & 870 & 26000 & 22 & 102 \\
9 & 31100 & 3600 & 0.12 & 2400 & 2070 & 86000 & 172 & 1866 \\
10 & 1980 & 2400 & 1.23 & 30 & 200 & 12800 & 8 & 17 \\
11 & 33000 & 2700 & 0.08 & 1300 & 1170 & 63700 & 113 & 1297 \\
12 & 3210 & 2400 & 0.75 & 74 & 256 & 18200 & 13 & 25 \\
13 & 42700 & 4300 & 0.10 & 1200 & 1040 & 63000 & 104 & 1837 \\
14 & 2900 & 1100 & 0.39 & 49 & 300 & 26000 & 16 & 32 \\
15 & 50000 & 960 & 0.02 & 3500 & 2100 & 73600 & 185 & 2530 \\
16 & 1280 & 1200 & 0.96 & 877 & 730 & 53800 & 62 & 211 \\
\hline
\end{tabular}

diversity $(r=0.77)$ and total diversity $(r=0.78)$ at $P<0.05$.

The $\mathrm{pH}$ values of the sites were all near neutral or slightly acidic (Table 3 ) with the EC in most serpentine sites higher than in the non-serpentine sites. Table 4 shows that the serpentine soils had high magnesium and low calcium concentrations as well as higher concentrations of metals such as chromium, manganese, iron, cobalt and nickel. However, the non-serpentine site (4) near the Noordkaap railway had very high total magnesium levels of $25800 \mathrm{mg} \mathrm{kg}^{-1}$. The $\mathrm{Ca} / \mathrm{Mg}$ ratios in the wetter serpentine soils differed significantly from the non-serpentine soil in the drier regions $(P=0.03)$. A PCA of the total metal concentration and the sites showed a clear separation of the serpentine and nonserpentine soils (Fig. 6). The first 2 axes of the PCA explain $97.4 \%$ of the total variance. The $\mathrm{P}$ values $(P>0.05)$ confirmed that there was no significant difference between the metal concentrations of the different sites. There was also no significant difference in the nutrient levels in the soils from the different sites $(P>0.05)$. Magnesium levels between serpentine and non-serpentine soils differed significantly in the wetter regions, but not in the drier regions $(P=0.018)$. Principal component analysis (PCA) of the soil characteristics and nutrient levels (Fig. 7; Table 5) grouped the non-serpentine soils together with the exception of site 4 (Basalt site in the Noordkaap reserve). The first 2 axes of the PCA of the soil characteristics and the sampling sites explained $99.3 \%$ of the total variance (Fig. 7).

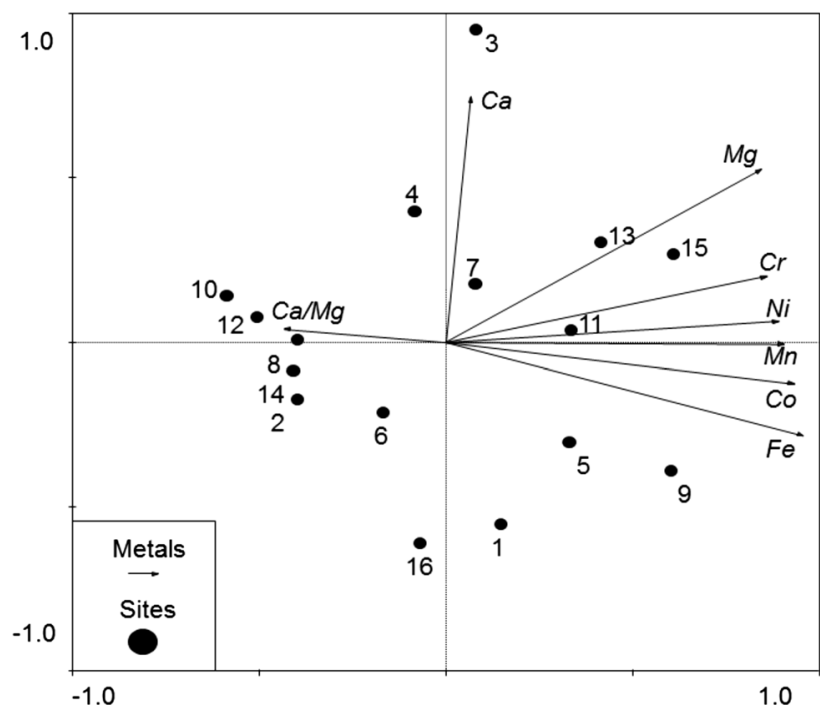

Fig. 6 Principal component analyses of some of the metals and sample sites of serpentine and non-serpentine soil

\begin{tabular}{llllll}
\hline Axes & 1 & 2 & 3 & 4 & Total variance \\
& & & & & \\
\hline Eigenvalues & 0.802 & 0.173 & 0.025 & 0.000 & 1.000 \\
Cumulative percentage & 80.2 & 97.4 & 100.0 & 100.0 & \\
$\begin{array}{l}\text { variance of species data } \\
\text { arian }\end{array}$ & & & & &
\end{tabular}




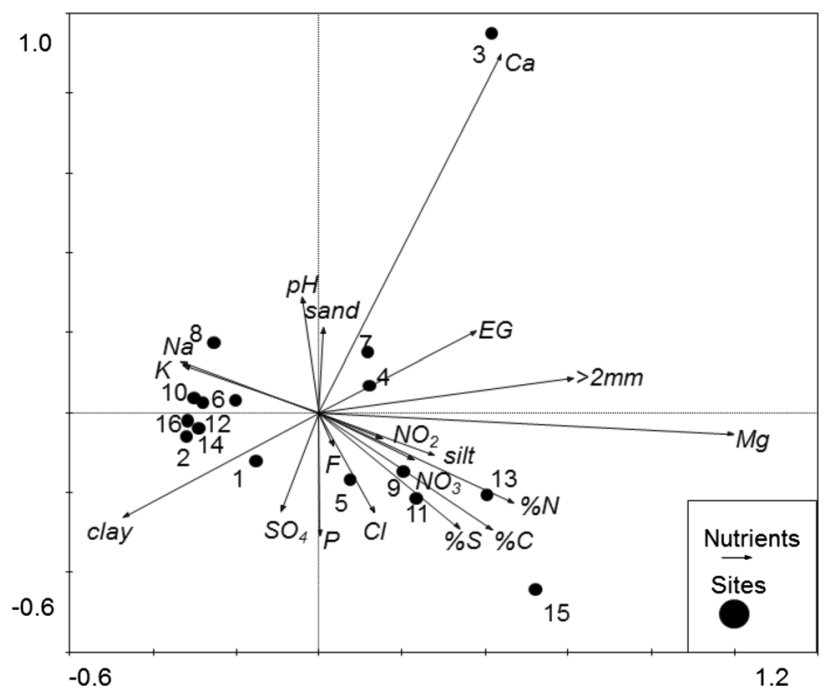

Fig. 7 Principal component analyses of the nutrients present in serpentine and non-serpentine soils

\begin{tabular}{llllll}
\hline Axes & 1 & 2 & 3 & 4 & Total variance \\
\cline { 1 - 4 } Eigenvalues & 0.895 & 0.098 & 0.004 & 0.002 & 1.000 \\
$\begin{array}{l}\text { Cumulative percentage } \\
\text { variance of species data }\end{array}$ & 89.5 & 99.3 & 99.7 & 99.9 & \\
\cline { 1 - 3 } & & & & &
\end{tabular}

Table 5 Nutrients present in soil samples measured in $\mathrm{mg}^{-1}$

\begin{tabular}{|c|c|c|c|c|c|c|c|c|c|c|}
\hline Sites & $\mathrm{Cl}$ & $\mathrm{Mg}$ & $\mathrm{Ca}$ & $\mathrm{Na}$ & $\mathrm{NO}_{2}$ & $\mathrm{NO}_{3}$ & $\mathrm{~F}$ & $\mathrm{P}$ & $\mathrm{K}$ & $\mathrm{SO}_{4}$ \\
\hline 1 & 11.8 & 438 & 33 & 8.57 & 0.13 & 2.3 & 0.61 & 23.7 & 22.13 & 19.6 \\
\hline 2 & 1.98 & 50 & 19 & 7.76 & 0.12 & 9.0 & 0.03 & 16.5 & 36.9 & 16.7 \\
\hline 3 & 1.00 & 1590 & 1050 & 7.44 & 0.26 & 6.8 & 0.12 & 14.7 & 15.5 & 3.9 \\
\hline 4 & 6.10 & 1030 & 276 & 7.85 & 0.31 & 34.2 & 0.15 & 15.1 & 19.6 & 35.2 \\
\hline 5 & 1.79 & 957 & 82 & 7.08 & 0.25 & 26.7 & 0.06 & 19.6 & 20.0 & 24.3 \\
\hline 6 & 3.38 & 306 & 130 & 8.43 & 0.20 & 25.9 & 0.05 & 21.5 & 61.0 & 13.2 \\
\hline 7 & 2.55 & 1013 & 337 & 8.16 & 0.39 & 60.8 & 0.11 & 25.7 & 48.5 & 17.3 \\
\hline 8 & 3.32 & 172 & 216. & 7.21 & 0.55 & 33.5 & 0.09 & 22.7 & 178.2 & 9.2 \\
\hline 9 & 2.41 & 1245 & 143 & 7.79 & 2.04 & 21.7 & 0.23 & 28.1 & 33.4 & 25.1 \\
\hline 10 & 1.73 & 79 & 97 & 8.10 & 0.61 & 3.4 & 0.15 & 17.7 & 34.3 & 7.0 \\
\hline 11 & 18.50 & 1322 & 106 & 7.85 & 0.29 & 156.3 & 0.02 & 19.4 & 52.5 & 27.6 \\
\hline 12 & 1.49 & 128 & 96 & 8.03 & 0.16 & 7.7 & 0.07 & 18.4 & 40.4 & 8.2 \\
\hline 13 & 5.15 & 1707 & 173 & 6.91 & 0.08 & 0.04 & 0.12 & 23.5 & 21.4 & 7.1 \\
\hline 14 & 3.37 & 116 & 45 & 7.56 & 0.10 & 1.4 & 0.05 & 19.4 & 22.5 & 35.2 \\
\hline 15 & 0.69 & 2000 & 39 & 6.80 & 0.29 & 5.7 & 0.14 & 17.9 & 16.3 & 4.8 \\
\hline 16 & 1.05 & 51 & 49 & 6.70 & 0.22 & 1.5 & 0.08 & 21.9 & 29.0 & 10.7 \\
\hline
\end{tabular}

\section{Discussion}

Use of both genotypic and phenotypic methods increases the chances of detecting the presence of a genus in a sample, as culture-based methods can promote the growth of some genera and suppress the growth of others (Dojani et al. 2014). With this approach, 60 genera were detected, with genera such as Acaryochloris, Annamia, Brasilonema, Chrocosphaera, Halomicronema, Planktothricoides, Rubidibacter, and Toxopsis reported for the first time for South African soil. Results con- firmed that algae and cyanobacteria are tolerant of most substrates and can even colonize environments with high levels of heavy metals and other nutrient imbalances, if moisture is present. Pessoa-Filho et al. (2015) found that even high nickel concentrations in serpentine soils did not affect enzyme activities of the microbial population. This study confirms the results of other studies (Orlekowsky et al. 2013; Schulz et al. 2016), demonstrating that edaphic factors do not play an important part in the growth of algae and cyanobacteria in extreme environments. However, edaphic factors may still play a role in 
the composition of the BSC. An interesting observation was the highest algal diversity, but low biomass was found in the red granite soil in Kaapsehoop, a nonserpentine site located in the fog belt. Molecular analyses also detected more genera in the mist belt sites than in the drier Lowveld areas. In contrast with the diversity, high numbers of cyanobacterial cells per gram soil, especially in Phormidium, were observed in the serpentine sites in the drier Lowveld region.

Acknowledgements We want to thank the staff at Eko-Analitika, North-West University, Potchefstroom for the soil analyses, Gustav Havenga for drawing the map of the study area and the National Geographic Society for financial assistance (NGS Grant \#9774-15). We also thank two anonymous reviewers for their constructive comments, which helped us improve the manuscript.

\section{References}

Alexander EB, Coleman RG, Keeler-Wolf T, Harrison SP (2007) serpentine geoecology of western North America: geology, soils and vegetation. Oxford University Press, New York

Altschul SF, Gish W, Miller W, Myers EW, Lipman DJ (1990) Basic local alignment search tool. J Mol Biol 215:403-410

Andrews S (2010) FastQC: a quality control tool for high throughput sequence data. http://www.bioinformatics. babraham.ac.uk/projects/fastqc/. Accessed 12 May 2017

Baker CCM (2016) Entrez_qiime: a utility for generating QIIME input files from the NCBI databases. http://github.com/ bakerccm/entrez_qiime release v2.0

Belnap J (2006) The potential roles of biological soil crusts in dryland hydrologic cycles. Hydrol Process 20:3159-3178. https://doi.org/10.1002/hyp.6325

Bolger AM, Lohse M, Usadel B (2014) Trimmomatic: a flexible trimmer for Illumina sequence data. Bioinformatics 30:2114-2120

Budel B, Darienko T, Deutschewitz K, Dojani S, Friedl T, Mohr KI, Salisch M, Reisser W, Weber B (2009) Southern African biological soil crusts are ubiquitous and highly diverse in drylands, being restricted by rainfall frequency. Microb Ecol 57:229-247

Cabala J, Rahmonov O, Jablonska M, Teper E (2011) Soil algal colonization and its ecological role in an environment polluted by past $\mathrm{Zn}-\mathrm{Pb}$ mining and smelting activity. Water Air Soil Pollut 215:339-348

Caporaso JG, Bittinger K, Bushman FD, DeSantis TZ, Andersen GL, Knight R (2010a) PyNAST: a flexible tool for aligning sequences to a template alignment. Bioinformatics 26:266-267

Caporaso JG, Kuczynski J, Stombaugh J, Bittinger K, Bushman FD, Costello EK, Fierer N, Gonzalez Pena A, Goodrich JK, Gordon JI, Huttley GA, Kelley ST, Knights D, Koenig JE, Ley RE, Lozupone CA, McDonald C, Muegge BD, Pirrung M, Reeder J, Sevinsky JR, Turnbaugh PJ, Walters WA, Widmann J, Yatsunenko T, Zaneveld J, Knight R (2010b) QIIME allows analysis of high-throughput community sequencing data. Nat Methods. https://doi.org/10.1038/nmeth.f.303

Castle S (2010) Chlorophyll- $a$ double extraction with methanol. Arid Lands Ecology Laboratory. http://www.colorado.edu accessed. Accessed 13 Feb 2012

DeSantis TZ, Hugenholtz P, Larsen N, Rojas M, Brodie EL, Keller K (2006) Greengenes, a chimera-checked 16S rRNA gene database and workbench compatible with ARB. Appl Environ Microbiol 72:5069-5072

Dojani S, Kauff F, Weber B, Budel B (2014) Genotypic and phenotypic diversity of cyanobacteria in biological soil crusts of the Succulent Karoo and Nama Karoo of southern Africa. Microb Ecol 67:286-301. https://doi.org/10.1007/s00248-013-0301-5
Edgar RC (2010) Search and clustering orders of magnitude faster than BLAST. Bioinformatics 26:2460-2461

Ettl H, Gartner G, Heynig H, Mollenhauer D, Komarek J, Anagnostidis K (1999) Susswasser von Mittleeuropa: Cyanoprokaryota, Teil 1: Chroococcales. Gustav Fischer Verlag, Stuttgart

Henriques M, Silva A, Rocha J (2007) Extraction and quantification of pigments from marine microalgae: a simple and reproducible method. Formatex 1:586-593

Hindak F (2008) Atlas of Cyanophytes. VEDA, Bratislava

Hotzel G, Croome R (1999) A phytoplankton methods manual for Australian freshwaters. Canberra: Land and Water Resources Research and Development Corporation Occasional Paper 22/99

Huber-Pestalozzi G (1961) Das Phytoplankton des Susswassers: Systematik und Biologie Tiel 5: Chlorophyceae (Grunalgen). Ordnung: Volvocales. E Schweizerbart'sche. Verlagbuchhandlung, Stuttgart

John DM, Whitton BA, Brook AJ (2002) Freshwater algal flora of the British Isles: a guide to freshwater and terrestrial algae. Cambridge University Press, Cambridge

Klindworth A, Pruesse E, Schweer T, Peplies J, Quast C, Horn M, Glockner FO (2013) Evaluation of general 16S ribosomal RNA gene PCR primers for classical and next-generation sequencingbased diversity studies. Nucleic Acids Res 41:e1

Komarek J, Anagnostidis K (2005) Cyanoprokaryota: Oscillatoriales. Spektrum Akademischer Verlag, Heidelberg

Kruger GHJ (1978) The effect of physico-chemical factors on the growth relevant to the mass culture of Microsystis under sterile conditions. PhD thesis, University of the Orange Free State, South Africa

Lamprinou V, Skaraki K, Kotoulas G, Economou-Amilli A, Pantazidou A (2012) Toxopsis calypsus gen. nov., sp. nov. (Cyanobacteria, Nostocales) from cave 'Francthi', Peloponnese, Greece: a morphological and molecular evaluation. Int $\mathbf{J}$ Syst Evol Microbiol 62:2870-2877. https://doi.org/10.1099/ ijs.0.038679-0

Masella AP, Bartram AK, Truszkowski JM, Brown DG, Neufeld JD (2012) PANDAseq: paired-end assembler for illumina sequences. BMC Bioinform 13:31. http://www.biomedcentral. com/1471-2105/13/31. Accessed 12 May 2017

McDonald D, Price MN, Goodrich J, Nawrocki EP, DeSantis TZ, Probst A, Andersen GL, Knight R, Hugenholtz P (2012) An improved Greengenes taxonomy with explicit ranks for ecological and evolutionary analyses of bacteria and archaea. ISME J 6:610-618

Mucina L, Rutherford MC (2006) The vegetation of South Africa, Lesotho and Swaziland. Strelitzia 19. SANBI, Pretoria

NSSSA (Non-Affiliated Soil Analysis Work Committee, Soil Science Society of South Africa) (1990) Handbook of standard soil testing methods for advisory purposes. Soil Science Society of South Africa, Pretoria

Orlekowsky T, Venter A, Van Wyk F, Levanets A (2013) Cyanobacteria and algae of gold mine tailings in the Northwest Province of South Africa. Nova Hedwiga 97:281-294

Pessoa-Filho M, Barreto CC, Dos Reis Junior FB, Fragoso RR, Costa FS, Mendes De Caralho, De Andrade LRM (2015) Microbiological functioning, diversity and structure of bacterial communities in ultramafic soils from a tropical savanna. Antonie Van Leeuwenhoek 107:935-949

Pires AC, Marinoni L (2010) DNA barcoding and traditional taxonomy unified through Integrative Taxonomy: a view that challenges the debate questioning both methodologies. Biota Neotropica 10: http://www.biotaneotropica.org.br/v10n2/ en/abstract?thematic-review + bn03110022010. Accessed 12 May 2017

Rajakaruna NB, Harris TB, Alexander EB (2009) Serpentine geoecology of Eastern North America: a review. Rhodora 111:21-108 
Schulz K, Mikhailyuk T, Drebler M, Leinweber P, Karsten U (2016) Biological soil crusts from coastal dunes at the Baltic Sea: cyanobacterial and algal biodiversity and related soil properties. Microb Ecol 71:178-193

Shade A (2015) Intro to QIIME for amplicon analysis. https://tinyurl.com/y84hkzn5. Accessed 12 May 2017

Smith MA, Rodriquez JJ, Whitfield JB, Deans AR, Janzen DH, Hallwachs W, Hebert PDN (2008) Extreme diversity of tropical parasitoid wasps exposed by iterative integration of natural history, DNA barcoding, morphology, and collections. PNAS 105:12359-12364

Taylor JC, Harding WR, Archibald CGM (2007) An illustrated guide to some common diatom species from South Africa. WRC report TT282/07

Ter Braak CJF, Smilauer P (1998) CANOCO Reference Manual and User's Guide to Canoco for Windows: Software for Canonical Community Ordination v 4. Microcomputer Power. Ithaca, New York

US EPA (1996) Method 3050B. Acid digestion of sediments, sludges, and soils. http://www.epa.gov/wastes/hazard/ testmethods/sw846/online/3_series.htm. Accessed 8 Aug 2017
Venter A, Levanets A, Siebert S, Rajakaruna N (2015) A preliminary survey of the diversity of soil algae and cyanoprokaryotes on mafic and ultramafic substrates in South Africa. Aust $\mathbf{J}$ Bot 63:341-352. https://doi.org/10.1071/BT14207

Wang Q, Garrity GM, Tiedje JM, Cole JR (2007) Naive Bayesian classifier for rapid assignment of rRNA sequences into the new bacterial taxonomy. Appl Environ Microbiol 73:5261-5267

Wehr JD, Sheath RG (2003) Freshwater algae of North America, ecology and classification. Academic Press, London

White TJ, Bruns T, Lee S, Taylor J (1990) Amplification and direct sequencing of fungal ribosomal RNA genes for phylogenetics. In: Innis MA, Gelfand DH, Sninsky JJ, White TJ (eds) PCR protocols: a guide to methods and applications. Academic Press Inc, New York, pp 315-322

Wickham H (2009) Ggplot2: elegant graphics for data analysis. ggplot2: elegant graphics for data analysis, vol 35. https://doi.org/10.1007/978-0-387-98141-3

Williamson SD, Balkwill K (2015) Plant census and floristic analysis of selected serpentine outcrops of the Barberton Greenstone Belt, Mpumalanga, South Africa. S Afr J Bot 97:133-142. https://doi.org/10.1016/j.sajb.2014.12.004 